\title{
SISTEM PENGOBATAN TRADISIONAL PADA MASYARAKAT GIRI JAYA
}

\author{
Oleh Ani Rostiyati \\ Balai Pelestarian Sejarah dan Nilai Tradisional Bandung \\ Jln. Cinambo No. 136 Ujungberung Bandung
}

Naskah diterima: 8 Januari 2010

Naskah disetujui: 12 Februari 2010

\begin{abstract}
Abstrak
Pada hakekatnya pengobatan tradisional merupakan bagian kebudayaan yang diturunkan dari generasi ke generasi berikutnya secara lisan atau tulisan. Oleh sebab itu kepercayaan terhadap pengobatan tradisional dapat terus bertahan, walaupun praktik biomedik kedokteran mengalami perkembangan. Untuk penyembuhan penyakit, dalam sistem pengobatan tradisional dicari lebih dahulu penyebab sakit atau etiologinya. Konsep etiologi ini perlu diketahui sebagai dasar untuk mendiagnosa penyakit yang kemudian diperlukan untuk menentukan caracara pengobatannya. Demikian pula pada masyarakat di Desa Giri Jaya Kabupaten Sukabumi yang menjadi lokasi penelitian, sebagian besar masyarakatnya masih melakukan pengobatan tradisional meskipun pengobatan modern telah dikenal. Untuk itu tulisan ini akan mengupas bagaimana persepsi masyarakat tentang sehat dan sakit, etiologi (sebab sakit), ciri penyakit, dan cara pengobatannya. Penelitian ini menggunakan pendekatan kualitatif dan tipe penelitian deskriptif.
\end{abstract}

Kata kunci: pengobatan tradisional, etiologi, Giri Jaya.

\section{Abstract}

In essence, traditional medicine is part of culture passed from generation to generation orally or in writing. Therefore, trust to the traditional treatment can continue to survive, although the practice of biomedicine medical growth. To cure disease, the traditional treatment system first sought the cause of illness or etiology. The concept of etiology is necessary to know as a basis for diagnosing a disease that then needed to determine the ways of treatment. Similarly in Desa Giri Jaya the regency of Sukabumi who became the location of research, most people still make traditional medicine even though modern medicine has known. Therefore this writing will discuss how the public perception of healthy and sick, etiology (cause pain), characteristic of the disease and how to treat it. This research uses qualitative approach and descriptive research type.

Keywords: traditional medication, etiology, Giri Jaya.

\section{A. PENDAhuluan}

Pada hakikatnya pengobatan tradisional di Indonesia merupakan bagian kebudayaan bangsa Indonesia yang diturunkan dari generasi ke generasi berikutnya secara lisan atau tulisan (Djlantik, 1983:3). Karena itu kepercayaan terhadap pengobatan tradisional di Indonesia dapat terus ber- 
tahan, walaupun praktik-praktik biomedik kedokteran mengalami perkembangan (Kasniyah, 1985: 71).

Pada masa sekarang pembicaraan tentang sehat dan sakit serta pandangan yang didasarkan pada pemikiran logis sudah berkembang baik apalagi setelah masuknya pemikiran modern melalui pendidikan formal. Namun dalam banyak hal pandangan yang didasarkan pada konsep kosmologi masih sering kelihatan menonjol sehingga mempengaruhi tingkah laku masyarakat dalam menghindari sakit atau dalam usaha memperoleh keadaan sehat (Yitno, 1985: 92). Meskipun pengobatan modern telah dikenal oleh masyarakat, tetapi ada juga sebagian masyarakat terutama yang tinggal di pedesaan masih menggunakan pengobatan tradisional. Demikian pula Desa Giri Jaya, salah satu desa di Kabupaten Sukabumi masyarakatnya masih menggunakan pengobatan tradisional. Hal ini bisa dilihat dari sistem dan cara pengobatan penyakit yang dilakukan. Permasalahannya adalah, mengapa dan bagaimana masyarakat melakukan pengobatan tradisional. Untuk itu tulisan ini akan mengupas bagaimana persepsi masyarakat tentang sehat dan sakit, etiologi (sebab sakit), ciri penyakit, dan cara pengobatannya. Adapun lokasi penelitian ini adalah masyarakat pedesaan tepatnya di Desa Giri Jaya Kecamatan Cidahu Kabupaten Sukabumi karena sebagian besar penduduknya masih melakukan pengobatan tradisional.

Pengobatan pada umumnya merupakan suatu strategi dalam menghadapi penyakit. Suatu strategi yang memaksa manusia untuk menaruh perhatian utama pada pencegahan dan pengobatan penyakit. Sementara itu dalam usahanya untuk menanggulangi penyakit, manusia telah mengembangkan suatu kompleks luas dari sistem pengetahuan, teknik, norma, nilai, sikap, adat istiadat, upacara, dan lambang yang saling membantu.

Sebagai bagian dari sub unsur kebudayaan, pengobatan tradisional mengacu pada sistem medisin atau pengobatan yang dicapai melalui proses dari mulut ke mulut, dari generasi ke generasi. Di sini karakteristik budaya dari masyarakat yang bersangkutan sangat besar pengaruhnya terhadap kondisi sistem ini. Hal ini berbeda dengan sistem pengobatan modern. Pada sistem pengobatan modern lebih banyak didasarkan pada logika ilmiah, karena konsep dan praktiknya bertolak dari hasil penelitian, pengamatan, dan pengujian ilmiah (Yitno, 1990: 3). Untuk menyembuhkan orang sakit, dalam sistem pengobatan tradisional dicari lebih dahulu penyebab sakit atau etiologinya. Konsep etiologi ini perlu diketahui sebagai dasar untuk mendiagnosa penyakit yang kemudian diperlukan untuk menentukan cara-cara pengobatannya (Kasniyah, 1985: 72). Ada dua konsep untuk mengetahui penyebab sakit (etiologi) yakni konsep personalistik dan naturalistik. Sistem personalistik adalah suatu sistem yang menunjukkan penyakit (illness) yang disebabkan oleh intervensi yang dapat berupa makhluk supranatural, makhluk yang bukan manusia (roh hantu, roh leluhur) maupun makhluk manusia (tukang sihir, dukun atau tukang tenung). Hal ini beda dengan konsep naturalistik. Dalam konsep naturalistik, penyakit (illness) dijelaskan dengan 
istilah sistematik. Sistem naturalistik mengakui adanya model keseimbangan; sehat terjadi karena unsur-unsur yang tetap dalam tubuh seperti panas, dingin, cairan tubuh, yin dan yang, ada dalam keadaan seimbang menurut usia dan kondisi individu dalam lingkungan alamiah dan lingkungan sosialnya. Apabila keseimbangan terganggu akan timbul penyakit (Foster dan Anderson, 1986:63-64).

Dari konsep tadi dapat kita peroleh pengertian secara umum bahwa konsep penyebab sakit adalah personalistik yakni sakit yang disebabkan oleh hal-hal bersifat supernatural. Sakit yang disebabkan karena hal-hal supernatural ini di kalangan masyarakat dikatakan "sakit yang tidak biasa", dan penyebabnya "dibuat orang", "kemasukan" dan lain sebagainya. Sedang konsep naturalistik mengacu pada sebab sakit yang lebih bersifat materi. Cara menentukan sakit lebih mendasarkan pada logika ilmiah. Masyarakat menyebut penyakit seperti ini dengan istilah "sakit biasa".

Demikian kedua konsep ini, personalistik dan naturalistik masih tetap hidup dalam alam pikiran masyarakat terutama mereka yang berorientasi pada sistem pengobatan tradisional, seperti yang sering kita jumpai di daerah pedesaan. Salah satu di antaranya Desa Giri Jaya Kecamatan Cidahu Kabupaten Sukabumi, tempat penelitian ini dilakukan.

Pendekatan yang digunakan untuk mencapai tujuan penelitian ini adalah kualitatif, yakni uraian monografis kasus untuk mendapatkan gambaran tentang sistem nilai, gagasan, ide, cara berpikir dan kepercayaan yang sifatnya abstrak dan menyeluruh.
Adapun tipe penelitian adalah deskriptif, yakni penelitian yang berupaya menggambarkan secara tepat sifat-sifat suatu individu, keadaan, gejala, atau kelompok tertentu, atau penyebaran suatu gejala adanya hubungan tertentu antara suatu gejala atau hubungan tertentu antara suatu gejala dengan gejala lain dalam masyarakat (Koentjaraningrat, 1981:42). Adapun metode penelitian yang dilakukan dengan teknik pengumpulan data melalui wawancara dan kepustakaan.

\section{B. HASIL DAN BAHASAN}

Desa Giri Jaya, tempat penelitian ini dilakukan, masyarakatnya mempunyai cara tersendiri untuk menentukan sistem pengobatan penyakit yang dideritanya. Desa Giri Jaya merupakan salah satu desa yang berada di Kecamatan Cidahu Kabupaten Sukabumi. Lokasi desa ini sekitar 5 kilometer dari ibu kota kecamatan, dengan jarak waktu tempuh kurang lebih $1 / 2$ jam. Desa ini berada pada ketinggian 800 meter di atas permukaan air laut yang memiliki bentang wilayah berbukit, berudara cukup dingin karena terletak di kaki Gunung Salak. Desa Giri Jaya terletak kurang lebih $12 \mathrm{~km}$ dari Cicurug arah barat daya dan berada di kaki Gunung Salak yang memiliki ketinggian 2.211 m. Suhu rata-rata antara $25^{\circ}$ sampai $40^{\circ}$ celsius.

Secara administratif Desa Giri Jaya dipimpin oleh seorang kepala desa yang dibantu 3 orang pegawai desa, 6 kepala urusan, dan 3 orang pelaksana. Desa ini mempunyai $8 \mathrm{RW}$ dan $29 \mathrm{RT}$, dan merupakan desa yang dikategorikan sebagai desa adat. 
Komunitas warga Desa Giri Jaya disebut sebagai komunitas adat yang dipimpin oleh seorang pemimpin adat yang biasa disebut dengan sebutan abah. Sebutan abah menunjuk suatu sistem kepemimpinan dari suatu komunitas atau kelompok sosial, di mana semua aktivitas anggotanya berlandaskan adat kebiasaan para orang tua (sepuh atau kakokolot). Terlihat dalam tata cara kehidupan mereka yang masih kukuh menjalankan tatali paranti karuhun (K.Adimihardja pada Rosyadi, 2005: 28). Kehidupan masyarakatnya termasuk kehidupan yang khas. Kepemimpinan masyarakatnya diatur oleh dua tipe kepemimpinan yakni pemimpin formal dan pemimpin informal. Kedua tipe kepemimpinan tersebut berjalan selaras dalam mengatur gerak dan langkah masyarakat Desa Giri Jaya.

Dalam sistem pengobatan suatu penyakit, masyarakat sebagian besar masih menggunakan sistem pengobatan tradisional. Sistem pengobatan tradisional ditentukan oleh persepsi mereka tentang sehat dan sakit dan penyebab sakit (etiologi). Dalam menyebutkan sakit, masyarakat pada umumnya mengaitkan dengan hal-hal yang supernatural (personalistik) begitu pula cara pengobatannya dilakukan dengan cara tradisional oleh dukun, orang tua, atau orang pintar. Persepsi masyarakat tentang sehat dan sakit, penyebab atau ciri-ciri penyakit, dan cara pengobatannya, selalu dikaitkan dengan alam semesta.

Biasanya masyarakat pedesaan dalam menentukan sehat jika orang itu tetap dapat menjalankan peranan sosialnya sehari-hari. Nanti pada saat menjalankan kegiatan mulai terganggu barulah dikatakan tidak sehat (sakit) dan baru diikuti usaha-usaha pengobatannya. Persepsi masyarakat tentang sehat, banyak dihubungkan dengan pekerjaan atau kemauan dan semangatnya untuk melakukan pekerjaan sehari-hari, artinya meskipun tampak sakit, pilek, pusing, dan batuk, mereka tetap melakukan pekerjaan sehari-hari dengan baik, masih merasa dalam kondisi sehat.

Masyarakat Giri Jaya pada dasarnya mempunyai persepsi tentang sehat, ada dua kategori sehat yang dikemukakan. Pertama, orang yang masih mampu beraktivitas bekerja di sawah atau di ladang, kedua adalah orang yang merasa badannya masih enak, mau makan, tidak cepat lelah, pulas tidur, dan bisa bepergian. Pada umumnya persepsi masyarakat Giri Jaya tentang sehat itu selalu dikaitkan dengan kemauan untuk melakukan pekerjaan di ladang (hutan) atau di sawah. Persepsi ini dapat saja dibenarkan, karena sebagian besar masyarakat adalah bekerja sebagai petani, baik petani ladang maupun petani sawah. Ukuran sehat bagi mereka adalah kemauan mereka yang sanggup untuk melakukan pekerjaan setiap waktu. Orang setempat menyebut mereka yang sehat itu adalah cageur (sehat dan kuat).

Persepsi tentang sehat untuk orang dewasa tidak sama atau berbeda dengan persepsi tentang sehat untuk anak-anak. Persepsi sehat untuk anakanak, apabila anak tersebut tidak rewel, mau makan dan bermain, sehat kalau kondisi sejak kecil baik, jarang sakit, dan pertumbuhan badannya normal. Persepsi penduduk Giri Jaya tentang sehat pada anak-anak itu berbeda 
dengan persepsi sehat pada orang dewasa. Persepsi sehat pada anak-anak dikaitkan dengan kemauan makan dan kelincahan anak untuk bermain, serta tidak lemah badan. Meskipun anak itu pilek, batuk tetapi selalu bergerak, makan banyak atau makan tidak sulit, bermain dengan anak yang lain, maka anak itu dikatakan sehat. Di sini ukuran sehat pada anak-anak adalah kemauannya untuk makan dan mau bermain. Persepsi penduduk Giri Jaya tentang sehat, baik pada orang dewasa maupun pada anak-anak selalu dikaitkan dengan kemampuan dan kemauan untuk melakukan aktivitas sehari-hari.

Adapun sakit, masyarakat Giri Jaya mengartikan sebagai cerminan adanya ketidakseimbangan yang diklasifikasikan menjadi dua golongan yaitu penyakit biasa dan penyakit tidak biasa (umum). Sakit biasa adalah sakit yang tampak akibat dari sesuatu yang nyata, mudah dicari penyebabnya dan pengobatannya, tetapi untuk sakit tidak biasa tampak sebagai penyakit yang disebabkan oleh hal-hal yang sulit diterima akal. Pada umumnya sakit tidak biasa selalu dikaitkan dengan halhal yang gaib. Masyarakat beranggapan sakit bila dirasakan badan tidak bisa beraktivitas, tidak enak, nafsu makan berkurang, dan tidak dapat bekerja.

Bagi masyarakat pedesaan termasuk masyarakat Giri Jaya, menentukan sehat jika orang itu tetap dapat menjalankan peranan sosialnya sehari-hari. Nanti pada saat menjalankan kegiatan mulai terganggu barulah ada pengakuan bahwa ia tidak sehat atau sakit dan baru diikuti dengan usaha penyembuhan atau pengobatan. Sehat dalam pengertian masyarakat petani berarti mau makan, mau jalan dan dapat bekerja. Semua pekerjaan terasa enteng (ringan, mudah). Sehat sebenarnya bersumber pada batin, kalau batin tenang, hati tentram, dan tidak banyak berpikir, maka keadaan fisik atau raga juga sehat artinya jika batin berkehendak, raga akan mengikuti.

\section{Etiologi Penyakit pada Masyarakat Giri Jaya}

Dalam masyarakat yang masih menonjolkan ciri ketradisionalan, sistem kesehatan dan etiologi didasarkan pada konsep-konsep budaya tradisional yang erat kaitannya dengan kondisi kultural dan lingkungannya (ekologi). Pemahaman etiologi penyakit ini tidak berdasarkan pada hasil pemahaman ilmiah melalui penelitian dan percobaan melainkan bertumpu pada pengalaman dari generasi sebelumnya melalui cara dari mulut ke mulut dan biasanya dipercaya begitu saja.

Sehubungan dengan itu etiologi penyakit (asal usul atau sebab penyakit) pada masyarakat Giri Jaya dibedakan menjadi dua golongan. Pertama adalah mendasarkan pada logika ilmiah yang cenderung menekankan pada hal-hal yang bersifat materi. Sehat terjadi bila organ tubuh ada dalam kondisi seimbang sehingga dapat menyeimbangkan adanya serangan dari faktor luar. Sebaliknya sakit akan terjadi jika keseimbangan menjadi terganggu. Sistem etiologi yang didasarkan pada pemahaman ini dikategorikan sebagai sistem etiologi natural. Sedangkan pada masyarakat pedesaan pada umumnya, penyakit yang disebabkan oleh faktor-faktor penyebab natural disebut penyakit lumrah atau biasa. Faktor penyebab 
yang bersifat natural dan mempengaruhi kesehatan misalnya karena cuaca, iklim, makanan, racun, bisa, kuman, bakteri, virus, tusukan atau kecelakaan dan sebagainya (Yitno 1990/1991:15). Di samping itu, ada lagi sebab lain misalnya dingin, panas, angin, udara lembab, dan unsur-unsur lain yang menyebabkan ketidakseimbangan dalam tubuh. Adapun cara penyembuhan dengan model keseimbangan dan keselarasan, artinya dikembalikan pada keadaan semula sehingga orang menjadi sehat kembali misalnya seseorang terkena sakit masuk angin, maka penyembuhannya dengan cara kerokan agar angin keluar, cara yang lazim dipakai pada masyarakat jika terkena sakit masuk angin.

Golongan kedua disebut sistem etiologi supernatural. Golongan ini didasarkan pada pemahaman bahwa yang menyebabkan sakit adalah faktorfaktor gaib atau supernatural. Sementara itu Foster lebih menyukai istilah personalistik. Menurut sistem etiologi personalistik penyakit ini disebabkan oleh intervensi suatu agen (perantara) aktif yang dapat berupa makhluk supernatural (makhluk gaib atau dewa) atau makhluk halus (hantu, roh leluhur, roh jahat) maupun manusia (tukang sihir atau tukang tenun, dukun). Di kalangan masyarakat pedesaan termasuk juga pada masyarakat Giri Jaya menyebut penyakit ini sebagai penyakit tidak wajar atau tidak biasa. Beberapa penyakit yang dilihat etiologinya secara personalistik antara lain kesurupan, terkena guna-guna, "dibuat" orang, dan lain sebagainya. Biasanya penyembuhan melalui pertolongan seorang dukun atau orang pintar.

\section{Jenis dan Ciri Penyakit serta Pengobatannya}

Masyarakat Giri Jaya umumnya masih berpandangan secara sederhana terhadap penyakit dan dalam sistem pengobatannya. Akan dilihat beberapa penyakit anak-anak dan dewasa yang biasa terjadi, meliputi jenis, nama (label), ciri atau tanda gejala (simpton), sebab penyakit (etiologi penyakit) dan cara pengobatan suatu penyakit. Dengan disajikannya beberapa penyakit berikut cara pengobatannya, akan tampak bahwa sebagian besar masyarakat Giri Jaya masih menggunakan sistem pengobatan tradisional dengan mengacu etiologi penyakitnya.

Banyak ragam penyakit, untuk itu dibatasi pada penyakit yang umun terjadi pada anak-anak maupun orang dewasa. Penyakit yang umum menyerang pada orang dewasa antara lain panas, malaria, mata, kepala pusing, perut, kulit gatal, sakit pinggang, sesak nafas, batuk, gigi, reumatik, diare, masuk angin (flu), pegal linu, kolesterol, disentri, dan salah urat. Sedangkan untuk anak-anak, penyakit yang umum menyerang adalah panas, batuk, cacingan, tampek, dan diare. Penyakit tersebut umumnya dianggap sebagai penyakit ringan dan biasa, oleh sebab itu dalam mencari sumber pengobatan biasanya dengan membuat ramuan jamu sendiri yang berasal dari akar-akaran atau dedaunan tumbuhan. Namun, dalam pelaksanaan warga juga sering menggunakan beberapa jenis obat yang dijual di warung untuk kesembuhan penyakit. Obat warung atau toko yang biasa dibeli untuk jenis 
penyakit tertentu misalnya procold, biogesig, bodrex, decolgen untuk obat sakit kepala, flu, dan masuk angin, diatab untuk penyakit perut, salep 88 atau ultrasilin untuk sakit kulit (gatal), dan reumazon untuk penyakit pegal linu. Jika sakitnya belum sembuh meskipun sudah diobati dengan jamu ramuan sendiri atau dibelikan obat di warung (toko), maka akan segera dibawa ke "orang tua" (dukun) atau Puskesmas. Puskesmas merupakan tempat terakhir penduduk yang sakitnya tidak kunjung sembuh meski sudah diobati.

Selain itu dukun atau orang pintar juga tempat tujuan penduduk untuk mencari pengobatan seperti mau melahirkan atau terkena guna-guna dan kemasukan roh halus. Dukun atau orang pintar adalah pengobat tradisional yang biasanya suka menolong sesama dan memiliki kemampuan dan pengetahuan esoterik yakni keahlian supernatural dan kekuatan magis (Ahimsa, 2006:43). Dukun biasanya memiliki kedudukan sosial di masyarakat, karena dianggap mampu memberikan pertolongan dengan imbalan jasa seadanya, namun ada syarat tertentu yang diminta misalnya rokok, tembakau dan lainlain. Ciri-ciri dukun umumnya berasal dari orang biasa, pendidikan rendah, tidak komersiil mencari uang karena tujuan untuk menolong sesama, punya pekerjaan tetap, dan ilmu yang diperoleh biasanya dari keturunan, lewat mimpi, wahyu dan lain lain.

Ada beberapa kategori dukun pada masyarakat Giri Jaya yang mempunyai perbedaan fungsi. Dukun bayi merupakan tempat tujuan orang yang melahirkan, pijat lelah bayi atau pijat lelah ibu bayi. Dukun tulang (omehan patah tulang) merupakan tempat tujuan orang keseleo (terkilir), jatuh, patah tulang atau salah urat. Dukun mantra merupakan tempat tujuan orang yang terkena guna-guna atau dibuat orang, dan orang yang kemasukan roh halus misalnya kesurupan atau terkena kawalat (kena kutuk karena melanggar pantangan).

Sedangkan beberapa penyakit yang dianggap berat oleh masyarakat Giri Jaya adalah jantung, paru, tumor, kanker, ginjal, tipus dan penyakitpenyakit lain yang memerlukan operasi atau kecelakaan. Untuk penyakit tersebut, biasanya mencari sumber pengobatan modern pada puskesmas atau rumah sakit yang ditangani oleh dokter, juru rawat, atau mantri kesehatan. Namun dalam kenyataanya, masyarakat sebelum mencari sistem pengobatan modern terlebih dahulu menggunakan pengobatan tradisional. Jika belum sembuh juga, baru dibawa ke puskesmas atau rumah sakit.

Demikianlah, masyarakat Giri Jaya membagi jenis penyakit menjadi beberapa bagian yaitu ringan, sakit berat, sakit biasa atau wajar, dan sakit tidak wajar. Ciri-ciri umum sakit berat adalah seakan-akan tidak mampu mengangkat tubuhnya sendiri tanpa pertolongan orang lain, tidak mau makan, tidak dapat merasakan apa yang disekelilingnya, dan penyembuhan sulit. Sedangkan ciri umum sakit ringan adalah masih dapat melakukan pekerjaan ringan, nafsu makan kurang, panca indera dan perasaan masih berfungsi dan penyembuhannya mudah. Sedangkan untuk sakit tidak biasa dihubungkan dengan tindakan menyimpang yang mengganggu keselarasan hubungan antara manusia dengan penciptanya, manusia dengan roh 
halus, dan manusia dengan manusia, tetapi badan halus ikut terlibat. Penyebabnya bersumber pada kekuatan gaib seperti kesurupan atau guna-guna. Adapun sakit biasa dihubungkan dengan tindakan menyimpang yang mengganggu keselarasan antara hubungan manusia dan lingkungan disekelilingnya (cuaca, iklim), misalnya masuk angin, pilek, batuk, cacingan, dan panas.

Selanjutnya di sini akan diuraikan beberapa penyakit yang biasa menyerang pada masyarakat Giri Jaya, baik pada anak-anak (bayi) maupun orang dewasa berikut dengan ciri (tanda), penyebab dan cara pengobatannya. Dengan diuraikannya beberapa penyakit tersebut, diharapkan memberi gambaran bagaimana persepsi masyarakat terhadap penyakit itu sendiri yang akhirnya mempengaruhi dalam mencari sumber pengobatan suatu penyakit.

Panas merupakan penyakit yang dianggap ringan dan biasa, karena biasa diderita oleh setiap orang baik anak balita maupun dewasa. Sebenarnya panas secara klinis juga merupakan penyakit berbahaya dan dapat menimbulkan kematian. Hal ini disebabkan ada kemungkinan panas adalah gejala permulaan dari sakit tipus atau demam berdarah, sehingga kalau tidak diobati secara serius bisa menimbulkan kematian. Namun bagi penduduk Giri Jaya, panas dianggap penyakit ringan dan biasa, sehingga pengobatannya cukup dilakukan sendiri atau membeli obat di warung (toko). Menurut warga desa ada beberapa ciri atau tanda yang merupakan gejala penyakit panas yaitu bagian muka, mata merah, badan panas, kepala pusing, dan jika panas semakin tinggi akan menjadi kejang. Sedangkan untuk anak balita, panas bermula dari keadaan hangat yang makin lama menjadi panas.

Menurut warga desa, panas disebabkan adanya wabah, pergantian musim atau kelelahan dalam bekerja. Adapun pengobatannya cukup dengan dikompres yang biasanya dengan ramuan sendiri, yaitu buah ketimun atau singkong diparut lalu ditempel ke dahi atau dilumuri ke seluruh tubuh supaya panasnya turun (dingin). Bisa juga dengan air garam lalu dikompres atau ramuan dari air, daun dadap serep, bawang merah, jeruk nipis kemudian dikompres. Setelah dikompres penderita harus tidur (istirahat) dan memakai kain selimut. Jika bangun tidur dan keluar keringat, ini berarti badan sudah enak dan akan sembuh. Untuk bayi jika panas cukup dibalur dengan asem dan bawang merah ditumbuk halus dan dicampur dengan minyak kayu putih serta jeruk nipis. Untuk anak balita, jika panas belum turun akan dibawa ke dukun bayi. Dukun bayi dikenal pandai dalam mengobati penyakit bayi atau balita dan membantu kelahiran serta pijat lelah bayi atau pijat lelah ibu. Oleh sebab itu seorang dukun bayi sangat dihormati oleh warga desa. Menurut sebagian besar masyarakat jika anak sakit panas belum sembuh meskipun sudah diobati, maka segera dibawa ke dukun bayi

Untuk penyakit malaria, warga biasa menyebut istilah panas tiris atau sakit panas dingin. Penyakit ini dianggap sebagai penyakit ringan dan biasa, karena biasa menyerang warga desa khususnya orang dewasa. Sebenarnya penyakit panas dingin ini secara klinis merupakan penyakit yang 
cukup berbahaya jika dibiarkan, namun bagi warga desa, dianggap penyakit biasa sehingga cukup diobati sendiri. Menurut warga desa ada beberapa ciri atau tanda yang merupakan gejala penyakit panas tiris yaitu seluruh tubuh panas tapi terasa dingin dan menggigil. Adapun penyebabnya menurut warga karena perubahan hawa mendadak, misalnya setelah kerja badan masih berkeringat (panas) langsung mandi (dingin), sehingga dapat menyebabkan badan panas dingin. Namun ada pendapat lain jika terlalu lama di pantai atau pesisir (panas), maka jika kembali ke rumah dapat terserang panas dingin. Penyebab sakit seperti ini biasa dihubungkan dengan penyebab sakit naturalistik, yaitu sakit disebabkan keadaan tubuh dingin dan panas sehingga unsur-unsur dalam tubuh menjadi tidak seimbang. Adapun penyembuhan menurut etiologi penyakitnya memakai model keseimbangan. Dalam hal ini masyarakat sering membuat minuman jahe yang direbus dan diberi gula jawa atau gula batu. Tujuan pemberian minuman jahe ini adalah supaya tubuh yang menggigil kedinginan menjadi hangat kembali. Seperti halnya penyakit panas yang sudah diuraikan sebelumnya disembuhkan dengan cara dikompres, artinya membuat keseimbangan bila badan dikompres dengan air dingin sehingga tubuh menjadi seimbang.

Demikian pula penyakit dingin yang biasa menyerang warga desa. Sakit dingin menurut bahasa setempat disebut ngahodhod (menggigil kedinginan), disebabkan oleh udara dingin, biasanya pada musim hujan. Penyembuhannya juga dalam model keseimbangan, yaitu warga desa biasa melumuri air garam pada tubuhnya kemudian dihangatkan dekat api atau juga membuat minuman air jahe hangat. Air garam dan jahe merupakan sumber panas yang mencairkan darah beku karena udara dingin, maka jika tubuh menggigil dingin diberi minuman air jahe panas atau tubuh dilumuri air garam atau dihangatkan dekat api, maka darah akan mencair dan mengalir kembali (tidak beku) sehingga tubuh menjadi hangat (sehat). Sakit menggigil kedinginan dan panas dingin, merupakan gambaran nyata prinsip keseimbangan dalam sistem naturalistik.

Untuk penyakit gatal pada kulit, warga desa menganggap sebagai penyakit ringan dan biasa. Ciri atau tanda yang merupakan gejala penyakit gatal adalah seluruh tubuh gatal atau keluar bintik (bercak) yang terasa gatal. Menurut warga desa, penyebab dari penyakit gatal ini adalah air kotor untuk mandi atau jarang mandi dan jarang ganti pakaian. Adapun cara pengobatannya warga desa biasa mandi dengan rebusan daun sirih yang airnya untuk mandi dan daunnya untuk sabun yang digosokkan pada bagian gatal. Atau bisa juga dengan dilumuri darah marmot atau kelinci. Jika dengan cara ini belum sembuh, maka membeli obat warung seperti salep gatal. Jika belum juga sembuh maka mereka datang ke dukun mantra. Tampaknya warga desa sangat percaya bahwa kesembuhannya karena mantra dari dukun. Mantra ini dianggap memiliki doa-doa yang mengandung kekuatan gaib atau supranatural sehingga dapat menyembuhkan suatu penyakit. Mantra hanya diketahui oleh dukun saja dan tidak boleh diceritakan kepada orang lain, karena ini merupakan rahasia dan dapat mengurangi kesaktiannya bila diceri- 
takan kepada orang lain. Biasanya ada syarat khusus bila minta pertolongan pada dukun, dalam istilah masyarakat Giri Jaya disebut abon. Abon ini bukan merupakan persyaratan mutlak melainkan hanya sebagai ucapan terima kasih, karena orang Sunda tempatnya rasa, jadi harus tahu menghargai, balas budi, dan menghormati. Abon diberikan sesuai dengan kemampuan dan ikhlas biasanya berupa rokok atau uang ala kadarnya.

Penyakit lain yang umum menyerang warga desa adalah sakit kepala. Sakit kepala dianggap penyakit ringan dan biasa. Menurut persepsi mereka, sakit kepala disebabkan karena banyak pikiran dan kurang tidur atau istirahat. Jika sakit kepala, maka harus banyak istirahat dan tidak banyak berpikir, juga harus minum teh panas. Banyak pikiran ini bisa disebabkan karena masalah anak, rumah tangga, pekerjaan, keluarga, ekonomi, dan lain sebagainya. Banyak pikiran menyebabkan orang yang kelihatan sehat tetap dikatakan sakit karena hatinya tidak tentram. Meskipun dari luar (lahir) tampak sehat tetapi dari dalam (batin) tersiksa tidak tenang, maka orang tersebut dikatakan sakit. Adapun ciri atau tanda yang merupakan gejala sakit kepala adalah kepala seperti ditusuktusuk, pening, dan tidak bisa untuk berpikir.

Apa yang diuraikan di atas tentang penyembuhan sakit kepala, adalah merupakan gambaran nyata prinsip keseimbangan dalam sistem naturalistik. Di mana seseorang yang terkena sakit kepala pengobatannya harus banyak istirahat. Pengobatan ini didasarkan pada sistem etiologi penyakitnya, yang memandang sakit kepala disebabkan karena banyak pikiran atau kurang tidur sehingga dengan istirahat diharapkan bisa sembuh dari penyakitnya. Tetapi bila dengan cara ini belum sembuh, warga desa biasa membeli obat sakit kepala di warung. Obat ini memang lazim dibeli warga desa untuk obat sakit kepala jika dengan cara istirahat belum juga sembuh. Atau bisa juga dengan pijat di bagian kepala untuk menghilangkan pusing.

Warga desa Giri Jaya juga menganggap sakit perut sebagai penyakit ringan dan biasa. Secara klinis sebenarnya penyakit perut cukup berbahaya karena kemungkinan gejala permulaan dari penyakit lain. Namun oleh warga desa dianggap penyakit ringan, oleh sebab itu pengobatannya juga dengan cara sederhana. Adapun ciri dari penyakit perut ini biasanya mulas dan terasa sakit. Menurut warga desa penyakit perut ini disebabkan oleh beberapa sebab yaitu sering makan buah mentah, minum air mentah, sering makan pedas atau asam, karena musim penghujan. Sedangkan pengobatannya biasanya dengan ramuan tradisional yang mereka ramu sendiri berdasarkan resep yang diperoleh secara turuntemurun dari nenek moyang yakni abu direndam air dengan garam dan setelah mengendap diminum.

Penyakit lain yang dianggap biasa atau lumrah adalah batuk. Batuk oleh warga desa dibedakan menjadi dua jenis yaitu batuk biasa dan batuk TBC. Batuk TBC adalah batuk yang disertai sesak nafas, sakit di dada, dahak berdarah atau dalam istilah kedokteran disebut TBC. Namun penyakit yang biasa menyerang warga desa adalah batuk biasa. Ciri atau tanda yang 
merupakan gejala penyakit batuk ini adalah tenggorokan gatal, serak, dan sesak nafas. Menurut warga desa, batuk ini disebabkan beberapa hal yaitu banyak minum air es, manis gula, banyak merokok, kemasukan debu, dan makan gorengan. Sedangkan pengobatannya biasanya dengan pengobatan tradisional yang diramu sendiri berdasarkan resep yang diperoleh dari orang tua atau leluhurnya. Ada beberapa cara dalam membuat ramuan yaitu kencur atau cikur diparut dicampur dengan gula batu lalu diendapkan semalam kemudian diminum, atau sirsak diberi gula batu lalu dikukus kemudan dimakan. Ada juga buah bligo diberi gula batu kemudian dikukus lalu diminum, atau jeruk pecel dicampur kecap dan garam, tapi juga bisa gula batu ditambah dengan madu kemudian diminum.

Pada waktu gejala awal batuk ini terjadi, biasanya belum berusaha diobati. Bila keadaan ini berlangsung terus berhari-hari, barulah mereka berusaha mencari pengobatan. Biasanya memanfaatkan sistem pengetahuan tentang obat-obatan tradisional yang dimilikinya. Jika dengan cara ini belum sembuh, mereka akan membeli obat di warung, dan apabila keadaan makin serius mereka bawa ke Puskesmas.

Untuk penyakit lain yang dianggap biasa dan ringan adalah masuk angin. Masuk angin merupakan penyakit yang umum menyerang warga. Ciri atau tanda yang merupakan gejala masuk angin adalah badan agak meriang, tidak enak badan, tidak semangat (lemes), dan perut kembung. Menurut warga desa penyebab masuk angin adalah pergantian udara, udara malam, kehujanan, kelelahan, kerja keras, dan terlalu banyak udara yang masuk ke tubuh sehingga perut kembung. Semua itu menyebabkan unsur dalam tubuh menjadi tidak seimbang, sehingga badan tidak sehat. Pada waktu gejala awal masuk angin ini terjadi, biasanya belum berusaha diobati. hanya tidur (istirahat) saja. Jika keadaan itu masih berlangsung terus, pertolongan selanjutnya adalah dikerok atau dibalur dengan balsem. Dengan kerokan, angin yang ada di dalam bisa keluar, sehingga perut tidak kembung dan badan terasa enteng kembali, begitu kata yang sering diungkapkan. Masuk angin dianggap sebagai penyakit yang umum dan biasa, sehingga penyembuhannya cukup dengan istirahat saja. Dengan istirahat (tidur) diharapkan penyakit dapat sembuh sendiri. Jika dengan cara ini tidak berhasil, pertolongan selanjutnya adalah kerokan dan bagian perut yang kembung diberi balsam atau minyak angin. Selain itu juga minum jahe hangat yang diberi gula merah dan merica. Dengan minum jahe atau pemakaian balsam ini diharapkan udara atau angin yang ada di dalam bisa keluar sehingga perut tidak kembung dan badan terasa enteng. Enteng di sini bisa diartikan bahwa unsur dalam tubuh kembali seimbang, sehingga badan menjadi sehat.

Penyembuhan masuk angin adalah merupakan gambaran nyata prinsip keseimbangan dalam sistem naturalistik. Seseorang yang terkena sakit masuk angin cukup istirahat dan memakai balsam atau minum Jahe. Pengobatan ini didasarkan pada sistem etiologi yang memandang masuk angin disebabkan karena lelah atau terlalu banyak udara (angin) masuk dalam tubuh sehingga dengan istirahat dan 
kerokan diharapkan angin bisa keluar sehingga perut tidak kembung dan tubuh kembali seimbang. Jika unsur dalam tubuh dalam keadaan seimbang maka badan akan terasa sehat.

Penyakit lain yang dianggap umum dan biasa adalah penyakit yang ada hubungannya dengan tulang yaitu sakit reumatik, sakit pinggang, terkilir, dan salah urat. Ciri atau tanda sakit reumatik adalah pegal linu dan sakit apabila digerakkan. Menurut warga desa, penyebab penyakit ini disebabkan jatuh, terlalu banyak bekerja atau sering mandi malam hari. Untuk sakit pinggang, ciri atau tandanya adalah pinggang terasa sakit, pegal bagian pinggang dan tidak bisa untuk membungkuk. Menurut warga desa, penyebab sakit pinggang ini adalah mengangkat benda yang terlalu berat. Sedangkan untuk penyakit terkilir, ciri atau tandanya adalah sakit pada anggota badan atau tulang yang terkilir. Menurut warga desa, penyebab terkilir ini adalah jatuh sehingga ada urat otot yang berubah. Demikian pula untuk sakit salah urat, mempunyai ciri yang sama dengan sakit terkilir, bedanya kalau salah urat disebabkan karena posisi badan, letak duduk, dan posisi tidur salah.

Pada waktu terjadi gejala awal penyakit pinggang dan terkilir, biasanya diobati dengan param beras kencur atau perasan beras kencur ditambah madu lalu diminum. Ada juga yang meminum rebusan daun lempuyang, kikoneng, kiurat, dan kumis kucing. Jika dengan cara ini belum sembuh, barulah mereka berusaha mencari pertolongan seorang dukun. Dalam hal ini dukun yang dimaksud adalah dukun omehan patah tulang (dukun tulang) yaitu orang yang pandai menyembuhkan penyakit yang berhubungan dengan tulang dengan cara dipijat. Ada 3 jenis sakit menurut dukun tulang, yaitu sakit karena pikiran, sakit karena otot tulang yang berubah, dan karena terserang penyakit. Sakit yang disebabkan karena otot tulang yang berubah inilah merupakan tugas dukun tulang misalnya terkilir, salah urat, patah tulang, sakit pinggang, dan reumatik. Seorang dukun tulang tahu jenis suatu penyakit dengan melihat ciri atau tanda khusus sesuai dengan pengetahuannya. Misalnya, seseorang dikatakan sakit pinggang bila orang tersebut jalannya terbungkukbungkuk menahan sakit. Obatnya, warga biasanya minum rebusan air daun rende. Orang yang sakit bagian pinggul bila jalannya terseok-seok. Orang sakit bagian punggung bila diangkat tangannya terasa sakit. Orang sakit kepala bila wajahnya merah berubah pucat, sedangkan orang yang sakit leher, lehernya terasa kaku dan tidak bisa diputar. Sebenarnya ada perbedaan antara dukun tulang dan dukun pijat. Dukun pijat dipandang sebagai tukang pijat atau tukang urut badan. Dukun pijat berurusan dengan orang-orang yang tidak enak badan karena lelah bekerja atau lelah karena bepergian jauh. Dalam menjalankan praktiknya dukun pijat menggunakan param beras kencur atau menggunakan minyak kelapa dengan parutan bawang merah. Fungsi param tersebut selain untuk mempermudah mengurut juga berfungsi untuk menghangatkan tubuh. Sedangkan dukun tulang mempunyai keahlian khusus yaitu memiliki pengetahuan tentang urat atau otot dalam tubuh manusia sehingga dapat 
membetulkan atau meluruskan kembali orang yang patah tulang atau salah urat. Dalam menjalankan praktiknya, dukun tulang juga menggunakan param beras kencur untuk mengurut atau memijat badan. Dukun tulang selain menggunakan pijat dan param, juga menggunakan ramuan dari tumbuhtumbuhan untuk pelengkap terutama pada pasien yang terkilir, patah tulang, dan salah urat. Tumbuhan tersebut adalah daun kiurat. Daun kiurat berfungsi untuk mempercepat penyembuhan dengan cara dibubuhkan pada bagian yang sakit lalu dipijat.

Umumnya warga Giri Jaya menggunakan param beras kencur sebagai pertolongan pertama. Jika belum sembuh mereka minta pertolongan seorang dukun pijat atau dukun tulang (omehan patah tulang). Dukun ini dianggap orang pandai yang dapat menyembuhkan penyakit yang ada hubungannya dengan tulang terkilir, reumatik, dan sakit pinggang. Penyembuhannya dengan cara dipijat atau diurut, menggunakan ramuan param beras kencur dan daun kiurat.

Penyakit lain yang dianggap biasa dan umum menyerang warga adalah sakit gigi. Sakit gigi yang biasa menyerang adalah gigi berlubang. Ciri atau tanda yang menjadi gejala penyakit gigi adalah gigi terasa "sakit". Bagi warga desa, gigi berlubang disebabkan karena dimakan ulat dan sering makan minum yang panas-panas dan dingin. Pada gejala awal biasanya penyakit ini belum berusaha untuk diobati, hanya dibiarkan saja. Jika makin serius, mereka berusaha mengobati, biasanya minum jahe panas sehingga rasa sakit bisa berkurang. Atau pada bagian yang berlubang diberi getah daun kamboja yang berwarna merah atau putih. Jika dengan cara ini belum sembuh, sebagian warga desa mencari sumber pengobatan pada dukun. Kalau sakit gigi sudah diobati dengan berbagai cara tapi belum sembuh juga, rasa sakitnya terasa luar biasa hingga penderita tidak bisa tidur, tidak bisa makan dan emosinya meninggi, maka orang tersebut pergi ke dukun mantra yang bisa menyembuhkan berbagai penyakit. Oleh dukun mantra, penderita diberi minuman air yang sudah dimantrai (diberi doa) dan beberapa hari kemudian sakitnya sembuh.

Air yang diberi mantra tersebut bisa menyembuhkan karena dianggap mempunyai kekuatan sakti yang bisa menyembuhkan berbagai macam penyakit. Umumnya jika sakit gigi warga desa enggan untuk pergi ke rumah sakit atau Puskesmas, mereka merasa takut jika gigi harus dicabut atau dibor untuk ditambal. Menurutnya jika dibor atau dicabut akan terasa sakit dan ngilu. Mereka lebih senang membiarkan gigi mereka berlubang dan gigi habis dengan sendirinya (tanggal sendiri) daripada dicabut atau ditambal. Tampaknya kesadaran tentang kesehatan gigi bagi masyarakat desa kurang dan masih ada anggapan takut jika gigi dicabut atau ditambal. Anggapan yang demikian ini menyebabkan warga desa menggunakan sistem pengobatan secara tradisional untuk penyakit gigi daripada pengobatan modern.

Adapun penyakit lain yang umum dan biasa menyerang warga desa adalah diare dan mata. Diare menurut istilah setempat disebut mencret, merupakan salah satu jenis penyakit perut. Ciri atau tanda yang menjadi gejala penyakit diare adalah perut mulas dan sering buang air besar 
berupa cairan atau tidak padat. Menurut warga desa, diare disebabkan karena sering makan buah mentah dan asam serta sering minum air mentah. Penyembuhannya, minum air garam sebanyak-banyaknya dan minum teh kental pahit. Fungsi dari air garam untuk mengganti air yang banyak keluar sehingga tubuh tidak menjadi lemas dan fungsi minum teh adalah menghentikan diare. Pahit dan kental ini diartikan agar dalam buang air besar nanti tidak berwujud cair lagi melainkan padat. Selain itu, untuk menghentikannya ada juga yang minum rebusan daun jambu.

Penyakit mata merupakan penyakit biasa yang dialami warga Desa Giri Jaya. Ciri atau tanda yang menjadi gejala penyakit mata adalah mata merah, perih, gatal, dan terasa ada kotoran yang mengganjal. Menurut warga desa, penyakit ini disebabkan oleh benda asing atau debu yang masuk ke dalam mata. Selain karena faktor tersebut, mereka percaya bahwa penyakit mata disebabkan karena wabah atau musim, oleh sebab itu penyembuhan biasanya dibiarkan saja, nanti akan sembuh sendiri. Atau, kalau mau diobati, diberi getah pohon nangka dan santan kelapa. Maksud pemberian ini agar benda asing atau debu keluar melalui getah dan santan kelapa. Jika belum sembuh juga, sebagian warga membeli obat mata di warung atau berobat ke Puskesmas.

Selain apa yang disebut di atas, terdapat juga beberapa penyakit lain yang biasa menyerang orang dewasa antara lain kencing manis (diabetes), demam berdarah, maag, tekanan darah tinggi, kencing batu, asam urat, dan penyakit kewanitaan. Kencing manis atau diabetes ditandai dengan sering buang air kecil, lemas, sering haus, banyak minum, dan turun berat badan. Obatnya, warga minum rebusan daun kumis kucing yang sudah dikeringkan. Daun kumis kucing banyak ditanam di sekitar rumah maupun hutan, sehingga mudah didapat warga. Jika belum sembuh juga, mereka berobat ke Puskesmas.

Penyakit demam berdarah merupakan penyakit yang cukup berbahaya dan ini sering tidak disadari oleh masyarakat. Sakit panas memiliki banyak indikasi, bisa merupakan gejala awal dari tipus atau demam berdarah. Jika sudah positip demam berdarah, maka warga selain minum obat dari dokter mereka juga minum jus buah jambu. Selain demam berdarah, penyakit tekanan darah tinggi dan asam urat juga dianggap berbahaya. Tanda atau gejala awal penyakit darah tinggi adalah kepala berat, pusing, cepat marah, dan mudah tersinggung. Warga desa minum rebusan daun babadotan atau daun cangkudu 'mengkudu' yang dianggap menyembuhkan atau setidaknya mengurangi rasa sakit. Adapun tanda atau gejala awal dari penyakit asam urat adalah tangan atau kaki sakit, nyeri, dan bengkak. Untuk mengurangi rasa sakit, maka warga desa minum daun babawangan yang banyak ditanam di sekitar rumah.

Untuk penyakit kewanitaan seperti keputihan dan setelah melahirkan, menurut warga desa ada beberapa ramuan yang bisa diminum. Gejala awal keputihan adalah keluar lendir putih, gatal dan berbau. Upaya untuk mengatasinya, warga desa biasa minum rebusan daun pepaya. Selain itu bisa juga minum rebusan daun jawer kotok, 
agar semua kotoran keluar. Demikian pula ibu-ibu yang baru saja melahirkan biasanya alat kelaminnya agak bengkak. Sebagai upaya agar rapat kembali dianjurkan minum rebusan daun sembung dan dibasuh dengan air daun sirih. Ada juga yang menggunakan abu kayu bakar yang masih terasa hangat dan dibungkus dengan kain untuk kemudian diletakkan di atas alat kelamin. Agar alat kelamin kembali rapat seorang ibu yang habis melahirkan dianjurkan untuk minum kunyit lempuyang dan kunyit gede, serta kakinya ditindih batu besar atau diikat sambil bersandar. Agar tidak gatal, ibu juga dianjurkan minum daun jawer kotok, tidak makan gorengan, dan membasuh kelaminnya dengan rebusan air daun sirih. Untuk kesehatannya, juga dianjurkan untuk adus 'mandi' air bunga (melati, mawar, kenanga, bokor, kaca piring), agar bersih lahir batin.

Selanjutnya akan dibahas pula di sini tentang penyakit-penyakit yang menyerang pada bayi dan anak balita. Penyakit tersebut adalah panas, morbili (tampek), cacingan, batuk, pilek, diare, kremi, dan sawan. Bagi masyarakat Giri Jaya, untuk menanggulangi penyakit tersebut caranya dengan membuat ramuan sendiri atau diobati ke paraji 'dukun bayi'. Hal ini disebabkan oleh anggapan bahwa penyakit ini sudah biasa diderita oleh anak-anak. Khusus untuk penyakit yang berhubungan dengan gangguan roh-roh halus biasanya harus ditangani oleh seorang dukun bayi, karena dianggap sebagai penyakit yang tidak biasa. Sedangkan untuk penyakit seperti panas, tampek, batuk, pilek, diare, dan kremi bagi masyarakat dipandang sebagai penyakit yang biasa saja. Oleh karena itu penyembuhannya bisa dengan cara diobati sendiri berdasarkan resep-resep yang berasal dari leluhurnya. Jika dengan cara ini tidak berhasil, maka mereka akan mencari pengobatan ke Puskesmas.

Pengobatan untuk bayi biasanya menggunakan param yakni ramuan bedak yang dioleskan atau dilulurkan pada anggota tubuh. Sebagai contoh adalah bedak wangi untuk menjaga kesehatan kulit. Selain param, ada juga tapel yang terdiri dari daun dadap dicampur dengan minyak dan diikatkan pada perut. Tapel ini digunakan untuk mencegah anak agar tidak masuk angin. Sedangkan jamu yang perlu diberikan pada bayi misalnya jamu tulak bala untuk menolak penyakit atau jamu agar anak mau makan. Di samping itu bayi juga perlu dipijat tiap sebulan sekali. Ada anggapan jika anak terlambat dipijat akan sakit dan sering menangis (rewel). Hal ini disebabkan karena bayi cepat lelah karena banyak gerak sehingga perlu dipijat. Peranan dukun bayi dalam hal ini cukup penting karena senantiasa dimintai tolong warga desa untuk menyembuhkan penyakit atau perawatan kesehatan. Selain dengan memijat, dukun bayi juga menggunakan mantra untuk menyembuhkan penyakit. Doa mantra biasa digunakan oleh dukun dalam mengobati penyakit, sehingga orang yang meminta pertolongan ke dukun terkadang mengatakan minta didoain, dalam arti minta diobati penyakitnya. Jamu, pijat, bobok, dan mantra merupakan sistem pengobatan tradisional yang dipakai dalam pengobatan dan perawatan kesehatan bayi dan anak pada masyarakat Giri Jaya.

Secara umum yang menjadi ciri bila anak sakit adalah penderita mengalami penyimpangan tingkah laku dari 
biasanya pada waktu sehat atau normal. Ada gejala seperti berat badan menurun, bermain berkurang, nafsu makan menurun atau anak menjadi rewel dan sering menangis. Kadangkadang juga disertai dengan suhu tubuh agak meningkat dan wajahnya pucat tidak segar.

Beberapa penyakit bayi atau anak akan dibahas di sini antara lain tampeg (morbili). Menurut mereka penyakit tampeg adalah bukan penyakit serius, dalam arti kurang berbahaya, asal bintik atau bercak merah mau keluar maka akan sembuh sendiri. Mereka membiarkan saja tanpa melakukan pengobatan yang serius, karena dianggap penyakit biasa yang diderita oleh anak-anak. Dengan kata lain setiap anak akan memperoleh kesempatan yang sama terserang tampeg, penyakit itu akan sembuh sendiri seiring dengan berlalunya waktu. Bercak merah umumnya dipaksa keluar dengan cara anak tersebut diberi minum madu dicampur daun melinjo. Selain itu warga desa Giri Jaya biasa menyembuhkan anak sakit tampeg dengan membakar daun kelapa kering di bawah tempat tidur anak tersebut. Namun, ada syarat utama yaitu daun kelapa kering yang jatuh sendiri tepat pada hari jumat kliwon. Ada kepercayaan, bahwa daun kelapa kering yang jatuh sendiri tepat pada hari jumat kliwon mempunyai kekuatan sakti yang jika dibakar maka akan mengeluarkan panas yang ada dalam tubuh si anak. Dengan keluarnya panas yang ditandai timbulnya bercak merah maka si anak akan sembuh dari penyakitnya. Selanjutnya jika si anak tersebut sudah sembuh dari penyakitnya, ia dimandikan dengan air yang diberi kembang melati, mawar, dan kenanga. Kalau ada kembang telon, jika tidak ada bisa kembang lain yang tumbuh di sekitar rumah. Maksud dari dimandikan adalah agar si anak tidak terkena penyakit tampek lagi. Masyarakat setempat mengatakan bahwa ini sebagai penangkal suatu penyakit, jadi ada pencegahan preventif suatu penyakit. Ada juga sebagian warga yang minta kesembuhan ke dukun mantra. Oleh dukun mantra anak tersebut disebor 'dimandikan' dengan air yang sudah diberi mantra.

Dilihat cirinya, menurut warga desa, penyakit tampek bermula dari panas badan yang tidak kunjung turun, oleh sebab itu si penderita perlu dikompres agar panasnya turun. Apabila setelah dikompres panas belum turun juga, barulah diberi sambetan daun jarak, dengan harapan kalau seandainya penyakit itu bukan morbili tetapi karena diganggu makhluk halus maka anaknya akan terhindar dari penyakit yang lebih parah lagi. Jika dengan cara ini belum sembuh juga dan mereka sudah mendapatkan tandatanda terserang penyakit tampek, maka mereka melakukan cara seperti di atas. Di samping itu mereka juga meminta pertolongan seorang dukun bayi agar anaknya diobati dengan menggunakan air yang sudah diberi doa lalu disemburkan ke ubun-ubun si anak.

Penyakit lain yang dianggap biasa menyerang anak atau bayi adalah diare atau menurut istilah setempat disebut mencret. Ciri atau tanda penyakit diare adalah sering buang air besar yang berupa cairan dan perut terasa sakit (mulas). Menurut warga desa, diare disebabkan karena anak sering makan buah mentah, air mentah, buah asam, atau makan yang 
menyebabkan tidak cocok sehingga perut sakit dan akhirnya diare. Diare juga dihubungkan dengan penyakit yang biasa diderita anak balita karena dianggap sebagai tanda anak yang mau pintar, misalnya anak mulai bisa duduk, berjalan, bicara, dan sebagainya. Pada kasus seperti ini penyembuhannya dengan cara sederhana yakni cukup si anak diberi minyak kayu putih di bagian perutnya agar terasa hangat, dan minum air garam untuk mengganti cairan yang keluar.

Cacingan juga merupakan penyakit yang dianggap biasa untuk anakanak, dengan ciri-ciri anak kurus, perut buncit, lambat pertumbuhannya, kurang nafsu makan, dan wajah pucat. Jika keadaan makin parah, anak akan lemas, kurus, dan tidak mempunyai tenaga. Secara klinis sebenarnya anak tersebut kekurangan malnutrisi (gizi) karena tidak mau makan. Penyakit cacingan juga disebabkan oleh anak sering minum air mentah, dimana di dalam air tersebut sering terdapat kotoran atau ulat yakni semacam cacing kecil. Adapun pengobatan untuk sakit cacingan yakni bagian pusar anak diberi ramuan rumput alas yang ditumbuk halus lalu dipopokkan di atas perut anak. Selain itu anak juga minum jamu pahit-pahitan seperti daun pepaya yang ditumbuk halus dan diperas atau rebusan temu ireng.

Pengobatan tersebut di atas merupakan gambaran nyata prinsip keseimbangan dalam sistem naturalistik, di mana anak yang sakit cacingan harus minum jamu pahit. Jamu pahit dalam pandangan masyarakat Giri Jaya dianggap berkhasiat untuk membunuh cacing yang bersarang dalam tubuh. Pengobatan ini didasarkan pada sistem etiologi penyakit, yang memandang sakit cacingan disebabkan karena ada cacing tanah yang masuk ke dalam tubuh, sehingga cacing ini perlu dikeluarkan dari tubuh dengan cara minum jamu pahit-pahitan.

Penyakit anak yang lain disebut sandekala yaitu kejadian yang timbul karena pelanggaran manusia terhadap aturan hidup, sehingga menyebabkan bayi atau anak mudah diganggu makhluk halus. Menurut masyarakat Giri Jaya, anak yang kemasukan roh halus, gejala awalnya termenung dan menangis histeris, kemudian melemah dan jatuh sakit dengan diikuti kejangkejang. Penyebabnya ada beberapa hal yakni merupakan sanksi terhadap tindakan orang tua yang kurang memperhatikan keselamatan anak atau bayi, berhubungan dengan gangguan mahkluk halus. Ada beberapa gejala seperti badan panas, sering menangis, rewel, kejang, dan mulut terkunci atau bibir terkatup. Anak ini terkena gangguan makhluk halus karena ada pantangan yang dilanggar. Misalnya, keluar rumah menjelang magrib. Pengobatan yang dilakukan adalah dengan cara pergi ke dukun mantra.

Gejala lain, seorang anak menangis terus-menerus sampai melonjaklonjak tidak mau diam meskipun sudah dihibur dengan berbagai cara. Penyebabnya adalah anak sering ditakuttakuti dengan kejadian yang biasa terjadi di malam hari lalu pada saat tidur terbangun dan menangis karena merasa takut dengan cerita yang pernah didengar. Gejala lain, juga ditemukan di lipatan paha, leher, atau paha terdapat warna merah dan kadang terasa gatal. Menurut masyarakat, hal itu disebabkan ibunya lupa memberi bedak pada anaknya saat menghadiri 
selamatan kematian. Oleh sebab itu sesuai dengan etiologinya, maka penyembuhannya mengambil bedak pada orang yang melakukan selamatan lalu dibedakkan pada si penderita. Jika dengan cara ini belum sembuh, maka minta pertolongan ke dukun bayi untuk dimantrai. Ada pula anak yang mendadak diare dan di bagian kulit timbul bercak merah. Penyebabnya karena bayi atau anak di ajak ke pasar atau bepergian jauh tanpa diberi penolak bala (panglay). Ada pula gejala lain yakni secara tiba-tiba anak sebentar menangis sebentar berhenti dan berteriak-teriak. Menurut masyarakat, penyebabnya orang tua sedang tidak tenang pikirannya atau banyak masalah sehingga terbawa ke anaknya. Sesuai dengan etiologinya, penyembuhannya diusahakan dengan cara orang tuanya tetap tenang, pasrah, dan tidak banyak pikiran. Selain itu juga melakukan upaya ke dukun minta doa.

\section{PENUTUP}

Desa Giri Jaya, merupakan desa yang sebagian besar masyarakatnya masih melakukan pengobatan tradisional. Pengetahuan tentang pengobatan pada umumnya berkaitan erat dengan sistem kepercayaan yang diyakininya. Untuk menentukan pengobatan atau penyembuhannya, selalu berpedoman pada kepercayaan dan lingkungan sekitarnya baik lingkungan fisik (alam) maupun sosial. Pengetahuan etiologi sakit didasarkan pada konsep-konsep budaya tradisional dan tidak berdasar pada hasil pengamatan, penelitian dan percobaan, melainkan bertumpu pada pengalaman pada generasi sebelumnya yang diturunkan secara lisan dan biasanya diterima begitu saja. Dalam sistem pengobatan tradisional aspek budaya dan ekologi memberi corak yang mendominasi.

Usaha penyembuhan sakit ini baik dalam sistem medisin modern maupun dalam sistem kesehatan tradisional, terlebih dahulu dicari sebab-sebab sakit atau etiologinya. Hanya bedanya dalam sistem medisin atau kesehatan modern untuk mencari sebab-sebab sakit lebih banyak didasarkan pada logika ilmiah yang bertolak dari hasil-hasil penelitian, pengamatan dan pengujian ilmiah, sedang pada sistem medisin atau kesehatan tradsional sebab-sebab sakit dicari dengan cara-cara tradisional yang dihubungkan dengan kepercayaan, nilai-nilai adat istiadat, lingkungan alam, tingkah laku. Dengan demikian secara tidak disadari oleh masyarakat yang masih mempunyai pola cara berpikir sederhana, dalam mencari sebab sakit dan usaha pengobatannya mereka sebenarnya menggunakan pendekatan ekologi. Tumbuhan-tumbuhan sekitar, dimanfaatkan dalam proses pengobatan seperti daun kumis kucing untuk kencing manis, daun harendong untuk luka, daun sirih untuk penyakit kewanitaan, dan lain sebagainya.

Etiologi penyakit penting peranannya dalam rangka penyembuhan dan pengobatan penyakit yang diderita seseorang. Faktor keterbatasan pengetahuan dan pendidikan masyarakat pedesaan yang sebagian besar petani itu cenderung mencari penyebab penyakit melalui sistem etiologi personalistik atau supernatural. Demikian pula masyarakat Giri Jaya, pada umumnya 
masih condong pada pandangan yang tradisional untuk mencari penyebab sakit dan cara penyembuhannya. Pengobatannya pun dilakukan secara tradsional menurut jenis penyakitnya, walaupun di daerah ini sudah terdapat Puskesmas pembantu yang disebut dengan Puskesdes yakni Pusat Kesehatan Desa yang terletak di bale desa.

Demikianlah, masyarakat Indonesia yang sebagian besar tinggal di pedesaan, sebagian besar penduduknya masih melakukan pengobatan tradisional. Mereka beranggapan apa yang dilakukan para leluhur dahulu adalah baik dan benar, inilah merupakan bagian kebudayaan yang mereka peroleh melalui proses lama secara turun-temurun. Dengan cara ini, sistem pengobatan tradisional tetap dapat bertahan di tengah berkembangnya praktik biomedik kedokteran (ilmu kesehatan modern).

Sepintas tulisan ini terkesan sederhana, namun dalam penelitian ini memberi tafsir lebih dalam tentang "medik tradisional" sebagai sudut pandang yang mendominasi wacana kesehatan pada masyarakat Indonesia terutama di pedesaan. Sistem pengobatan tradisional yang dilakukan masyarakat Giri Jaya ditentukan oleh etiologi penyakitnya yang pada akhirnya bermuara dalam penentuan pengobatannya. Peran serta pengobat tradisional (dukun, orang pintar atau paraji) sangat penting dalam sistem pengobatan tradisional, oleh karena itu perlu adanya pembinaan dan pelatihan untuk dilibatkan dalam pembangunan kesehatan masyarakat. Pengobatan dengan memanfaatkan tanaman obat (tumbuh-tumbuhan sekitar) perlu diberi penjelasan secara benar dan ilmiah, sehingga manfaatnya lebih terasa. Jangan sampai mereka salah dalam memberi tafsir, sehingga menimbulkan dampak yang negatif (bahaya). Untuk itu pemerintah, dalam hal ini tenaga kesehatan bekerja sama dengan aparat desa juga pemimpin informal (ketua adat) dan pengobat tradisional, bersama-sama membangun kesehatan masyarakat.

\section{DAFTAR PUSTAKA}

Ahimsa Putra, HS. (ed). 2005. Masalah Kesehatan dalam Kajian Ilmu Sosial-Budaya Yogyakarta: Kepel Press.

Saifuddin, Achmad Fedyani. 2006. Antropologi Kontemporer. Suatu Pengantar Kritis Mengenai Paradigma. Jakarta: Kencana Prenada Media Group.

Yitno, Amin, 1990/1991.

"Kosmologi dan Dasar Konsep Kesehatan Pada Orang Jawa", dalam Celaka, Sakit, Obat, dan Sehat Menurut Konsepsi Orang Jawa. Jogyakarta: Javanologi.

Foster dan Anderson. 1986. Antropologi Kesehatan. Jakarta: UI.

Koentjaraningrat. 2004.

Kebudayaan Jawa. Jakarta: Balai Pustaka.

Mulder, Niels. 2007. Di Jawa, Petualangan Seorang Antropolog. Yogyakarta: Kanisius.

Kasniyah, Naniek. 2006.

"Penyakit Asam Urat dan Pengobatannya". Esei-esei Antropologi. Teori, Metodologi dan Etnografi. Yogyakarta: Kepel Press. 